Anna Budzyńska,

\title{
Prediction of global sugar prices after abolition of EU sugar quotas
}

\author{
Predykcja globalnych cen cukru po zniesieniu unijnych kwot cukrowych
}

\section{Introduction}

Sugar production plays an important role both in the global economy and at the national level not only due to the participation of the industry and related farmers, suppliers and intermediaries in generating GDP, but mainly due to the significant demand from households and the industry which uses sugar as an intermediate. Sugar is used in many sectors of the agri-food industry, as well as in the chemical, pharmaceutical and fodder industries. As a result, the sugar market influences the development of other industries and branches of the economy. For end users, sugar is a necessity, therefore every inhabitant of the globe is part of the supply chain on the global sugar market. Even the fact that the consumption of sugar in households tends to decline does not diminish this role, as total sugar consumption in the world increases year by year, mainly due to increasing consumption by related industries using sugar for further processing.

One can use two classification criteria when sharing the world sugar market. The first one is based on the raw material from which sugar is produced, i.e. sugar cane and sugar beets. The raw material used often determines the competitive position of the domestic sugar industry in the international arena, as it is closely related to specific production costs and consumer preferences. Cane sugar is generally produced at lower costs, the raw material is easier to obtain, and customer preferences tend to choose this product. As a result, beet sugar is losing importance in the global economy, despite the fact that the market 
leaders for many decades were EU beet sugar producers. They achieved a high commercial and competitive position thanks to the instruments used to support sugar production. The second classification criterion are the mechanisms of state intervention used in individual countries, the purpose of which is to increase the profitability of domestic sugar producers. The areas where there are administrative regulations are mainly the European Union countries, the United States, Brazil, India and China, which compete on the global market with producers operating in the conditions of complete liberalization, who make decisions solely based on market principles.

The activities of the World Trade Organization (WTO) force the liberalization of the elements used so far to support agri-food producers in countries using intervention tools, including those applicable to sugar producers and traders (United Nations Conference on Trade and Development, 2007). The results of the negotiations already at the end of the 20th century obligated the countries that used support to reduce it on many levels. Kraciuk (2016, pp. 69-78) observed that as a result of the opening of EU countries' domestic markets to global sugar imports from third, non-EU countries, a reduction in customs tariffs and a reduction in expenditure on subsidizing exports amounted to $36 \%$, which directly affects the level of world sugar prices.

The highest level of support was used in the European Union countries, thanks to which the EU producers received higher prices on the domestic market, significantly overstating the prices on the world market (OECD 2019, pp. 270). The aftermath of the obligations towards the WTO was the reform of the EU sugar market introduced in 2006, which reduced the official prices by the required 36\%. It ended in 2017 with the abolition of production limits. The most important changes to which the reform contributed took place in South American and Asian countries, where the sugar industry, producing cheaper cane sugar, developed rapidly and dynamically, increasing the share of these countries in the international sugar trade. It also directly influenced the level of sugar prices on the world market.

The presented situation raised the authors' interest in the relationship between limiting the impact of mechanisms of state interventionism, especially on the EU market and global sugar prices on the world exchanges, where futures contracts are used as the global benchmark for the pricing sugar. An attempt was made to identify how deregulation measures applied in the European Union affect sugar price levels. Moreover, an attempt was made to use various models describing the analysed phenomenon, which were used to forecast the level of sugar prices in the world after the lifting of restrictions on domestic markets. 
In achieving the set goals, simple statistical methods were used to analyse the trends characterizing the level and volatility of world sugar prices in the years 1990-2020 on a monthly basis. However, in order to provide a forecast of the sugar price on world markets, three models were used: the development trend, the Winters model and the ARIMA model. After analysing the mean square error of ex post prediction of expired forecasts, the best model for the presentation of the predictions will be selected.

The paper discusses the types of scenarios after reducing the government support used on the sugar market, mainly in the European Union, in which the most numerous aid instruments were used. In the next part, a review of current forecasting models was carried out together with a discussion of forecasts made with their help. Then, an analysis of trends characterizing sugar prices on major global stock exchanges was performed, which culminated in the 3 forecasting models, described in the last part of the paper, together with a forecast of the future directions of sugar price development.

\section{Literature review}

Changes taking place in the global economy are leading towards greater liberalization. The processes of limiting the instruments regulating the sugar markets in individual countries are progressing in the same direction. This affects the price level in individual domestic markets and the prices of international trade. Due to numerous restrictions on the support instruments used so far, many authors have made an attempt to predict changes in the level of sugar prices on the world market.

First, there has been a reorganization of the Common Agricultural Policy in the European Union. However, despite many reforms, there are still many mechanisms supporting entities using various forms of subsidies and aid funds. On the one hand, the level of state intervention in the EU sugar market has been reduced, on the other hand, many still exist, even if not directly related to the sugar market, but available to market participants in a different form. The use of these often contradictory CAP instruments, according to Dworak and Grzelak (2015, pp. 6-17) can lead to a weakening of the competitiveness of those sectors of the EU agriculture, which are characterized by a disproportion in development compared to highly developed countries.

On the other hand, Pörksen (2012, pp. 3-4) claims that on the EU sugar market, as in any other agri-industrial sector, vertical integration of growers with 
sugar factories is necessary, regardless of the country where sugar production is located, because without it, it is not possible to maintain the competitiveness of the entire sector community developed so far.

Accurate forecasts, predicting not only the direction but also the size of changes in individual indicators in national and regional terms, were provided by the CAPRI (Common Agricultural Policy Regionalized Impact) model constructed by Adenäuer (2008), which by analysing the partial equilibria of supply and market modules made it possible to present the likely behaviour of producers and consumers on individual agricultural markets. The reduction of sugar production by 2020 by almost $13 \%$ in the entire EU was assumed, as a result of which prices on the internal market can be expected to increase. The results of the above simulations were confirmed in theoretical studies commissioned by the European Commission, done by the European Economic Interest Grouping (AGROSYNERGIE, 2011, pp. 162). The overall conclusion of their analysis was to reduce the amount of sugar produced in countries with higher production costs due to the reduction in the area of beet plantations and to maintain a constant volume of sugar produced in regions with lower production costs, which was mainly associated with a fall in prices on the internal market after reducing government support for sugar beet producers and sugar factories. This was confirmed by another prediction of the European Commission, according to the report of which the sugar prices in the Member States are expected to fall below the reference threshold, and thus below the average sugar production costs. In addition to reducing the profitability of production, this will also reduce the competitiveness of the EU, including Polish sugar exports (European Commission Report, 2015, pp. 2).

Similar simulations were presented five years earlier by Gohin and Bureau (2006, pp. 239), according to which they forecasted a 10\% global drop in EU sugar production due to the fall in world sugar prices. The convergence of the above predictions in the following years was confirmed by the research conducted by Nolte, Buysse and Huylenbroeck (2012, pp. 86), the conclusions of which assume an increase in sugar production in Eastern Europe, mainly in Poland, after the abolition of administratively determined sugar prices, assuming their drastic decline of over $30 \%$ both in the EU and dawn market.

Since October 2017, the Congress of the International Confederation of European Beet Producers (CIBE) informed about the drastic changes in the EU sugar industry, which provided for an increase in competition between beet crops and alternative crops, due to the forecasted significant reduction in the prices of sugar and raw materials used in its production. Hence, the proposed 
activities should focus on two areas. First, the prices paid to beet growers should cover not only the costs of their production, but also ensure long-term profits. It is also important to increase the automation of raw material quality assessment, which will have a direct impact on the reliable assessment of the value of the delivered beet, and thus ensure adequate payment. The second important aspect is the activities aimed at reducing the level of the tools of state intervention used in the main world producers and exporters of sugar. While the European Union conducts an active policy of deregulation on the sugar market, its main competitors on the global market apply a number of regulations and mechanisms to support domestic sugar industries, which, combined with a large number of granted preferential import concessions for sugar from third countries, significantly reduces the competitiveness of EU exports (Resolutions of XLIV Congress CIBE, 2015).

A different but important idea can be found in the research by Maitah and Smutka (2019, pp. 7), who drew attention to the influence of speculators on sugar prices on global stock exchanges. The authors believe that speculators contribute to the artificial distortion of sugar prices, which likely increases the frequency of price fluctuations and contributes to their destabilization in the future, thus introducing uncertainty in traditional supplier-consumer contracts.

\section{Research methodology}

International sugar trade took place not only based on agreements between specific countries, but also based on the market relation of supply and demand, which was reflected in transactions concluded on commodity exchanges. The subject of international stock exchange trade was both raw sugar, which was then refined before being sold to the final consumer, and refined white sugar. The basic determinant of prices for white sugar intended for international trade were the quotations of the indicators. They were shaped on the LIFFE futures exchange in London, where in the transactions scheduled for March, May, August, October and December, contract no. 5 was sold. The price determinant for raw sugar was the NYBoT futures exchange in New York, where, under contract No. 11, sugar was sold in March, May, July and October, and its quotations determined the prices for trading between transactions concluded on the exchange.

The construction of the forecasting model for refined and raw sugar prices was based on a time series of sugar prices on world exchanges - London and New York in 1990-2020. The data is the implementation of a stochastic process, the 
domain of which is time, i.e. a sequence of information about prices arranged in time, the measurements of which are performed with an exact time step (in our case - monthly). Data are from the United States Department of Agriculture (USDA) Economic Research Service.

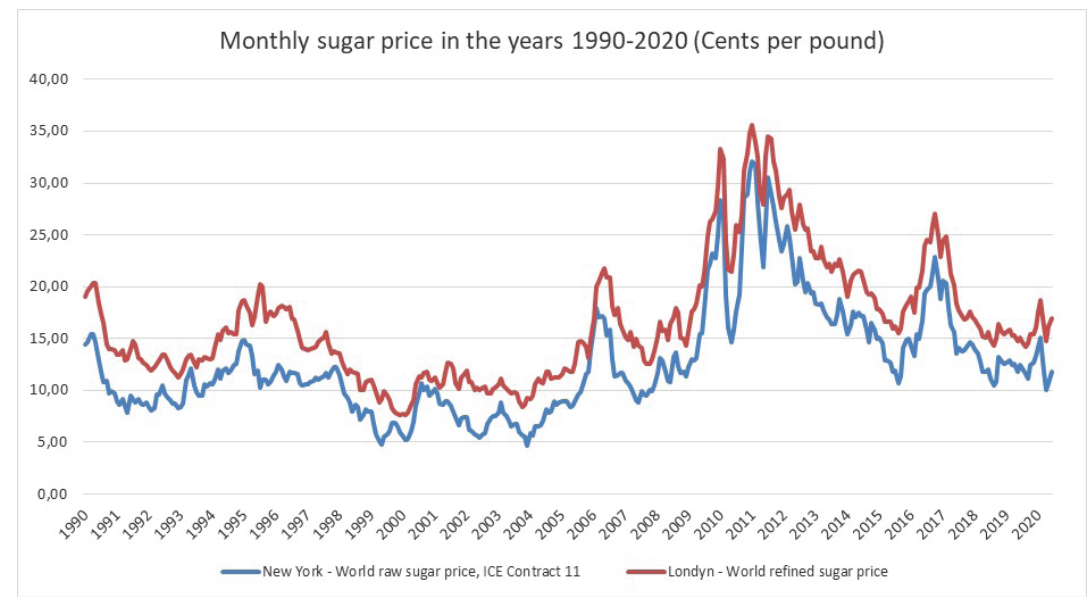

Figure. 1. Monthly prices of white and raw sugar in 1990-2020 (cents per pound).

Source: own study based on www.ers.usda.gov/data-products/sugar-and-sweeteners-yearbook-tables/ sugar-and-sweeteners-yearbook-tables (07.07.2020).

The analysis of the dispersion of points in the presented series indicates their significant similarity. Refined sugar prices are higher than raw sugar prices because they are the next stage in the processing of sugar, the main raw material of which is raw sugar. The significant similarity of the presented series is indicated by the Pearson linear correlation coefficient. Its value was 0.976 (it is statistically significant at the level of 0.01 ), which proves a very strong positive correlation. Both series contain 366 monthly averages of sugar prices quoted on the London and New York stock exchanges. The collected data will allow to build a model that will be used to forecast refined and raw sugar prices in the next 12 months (from July 2020 to June 2021).

Three approaches were used to build the forecasting model: dynamic econometric model (linear trend), exponential smoothing model (Winters model) and non-stationary time series model (ARIMA).

The task of econometric modelling is to indicate the correctness of changes in the level of the analysed phenomenon over time. Dynamic econometric models are used for this. A characteristic feature of these models is taking into account the time factor to explain the shaping of the level of the analysed phenomenon. 
These models are divided into two groups: those in which time is represented by an intrinsic exogenous variable and those in which there are lagged variables (Gruszczyński \& Podgórska, 2004,pp. 173). Models in which the set of exogenous variables contain only the time variable $(t)$, where $t=1,2, \ldots, n$ (where $t$ is the next number of the period: day, week, month, quarter, year) are called developmental tendency models (or trend models). Depending on the course of the studied phenomenon over time, various analytical forms of the trend model are used. In our analysis, a linear model of the following form was used:

$$
y_{t}=\alpha+\beta t+\varepsilon_{t},
$$

where:

$\mathrm{y}_{\mathrm{t}}$ - level of the analysed phenomenon in $\mathrm{t}$ time unit,

$\alpha, \beta$ - model parameters,

$\mathrm{t}$ - time variable $\mathrm{t}=1,2, \ldots, \mathrm{n}$ ),

$\varepsilon_{t}-$ random component characterizing the effects of the impact of random fluctuations on the development trend of the series.

We assume that the random components have normal distributions with zero expected value, variance $\sigma^{2}$ and that they are independent (Chow, 1995, pp. 17).

The parameters of this model are estimated by the method of least squares (Greene, 2012, pp. 66-113). The advantage of these models is an extensive mathematical apparatus, thanks to which it is possible to effectively identify the model, estimate its parameters, provide a comprehensive assessment of the model quality and interpret the obtained results. These models only describe the behaviour of the studied variable over time, which is not a direct cause of changes occurring in its values, but it synthesizes the impact of factors not known more closely, creating the possibility of describing these changes in a quantitative manner. Therefore, these models have limited cognitive values, not allowing to indicate the source of variability of the examined variable and cause and effect relationships between the variables that shape it. They also ignore the seasonality in the analysed phenomenon. The forecast for subsequent periods is determined as follows:

$$
y *_{T} a+\mathrm{bT},
$$

for $\mathrm{T} \in<\mathrm{n}+1 ; \mathrm{n}+\mathrm{t}>$; where:

$\mathrm{t}$ - means the farthest period for which forecasts are acceptable, $a$ and $b-$ are assessments of $\alpha$ and $\beta$ parameters. 
The Winters model belonging to the class of exponential smoothing models can be used to analyse time series containing development tendency, seasonal fluctuations and random fluctuations (Cieślak, 1997, pp. 76). It comes in additive and multiplicative versions with the following form: additive:

$$
\begin{aligned}
& F_{t-1}=\alpha \cdot\left(Y_{t-1}-C_{t-1-r}\right)+(1-\alpha) \cdot\left(F_{t-2}+S_{t-2}\right) \\
& S_{t-1}=\beta \cdot\left(F_{t-1}-F_{t-2}\right)+(1-\beta) \cdot S_{t-2} \\
& C_{t-1}=\gamma \cdot\left(Y_{t-1}-F_{t-1}\right)+(1-\gamma) \cdot C_{t-1-r}
\end{aligned}
$$

multiplicative:

$$
\begin{aligned}
& F_{t-1}=\alpha \cdot \frac{Y_{t-1}}{C_{t-1-r}}+(1-\alpha) \cdot\left(F_{t-2}+S_{t-2}\right) \\
& S_{t-1}=\beta \cdot\left(F_{t-1}-F_{t-2}\right)+(1-\beta) \cdot S_{t-2} \\
& C_{t-1}=\gamma \cdot \frac{Y_{t-1}}{F_{t-1}}+(1-\gamma) \cdot C_{t-1-r}
\end{aligned}
$$

where:

$\mathrm{F}_{\mathrm{t}-1}$ - the equivalent of a smoothed value obtained from the simple exponential smoothing model (mean value evaluation),

$S_{t-1}$ - evaluation of the trend increase at the moment or period $t-1$,

$\mathrm{C}_{\mathrm{t}-1}-$ assessment of the seasonality index for the moment and period $t-1$, $\mathrm{r}$ - length of the seasonal cycle,

$\alpha, \beta, \gamma$-parameters of the model, with a value in the range $[0,1]$.

The advantage of exponential smoothing methods is the possibility of modelling non-stationary and heteroscedastic time series. An unquestionable disadvantage is the inability to introduce exogenous variables into the model.

Forecasts for the moment or period $\mathrm{t}>\mathrm{n}$ are calculated from the equation:

$$
y *_{t} F_{n}+S_{n}(t-n)+C_{t-r}
$$

for the additive model

$$
y *_{t}\left[F_{n}+S_{n}(t-n)\right] \cdot C_{t-r}
$$

for the multiplicative model. 
Most of the ranks encountered in economic realities are not stationary ${ }^{1}$. Additional transformations, e.g. decomposition or differentiation, are necessary. For such prepared series, various types of stochastic processes are useful for modelling them: the moving average (MA) process, the autoregressive process (AR), the autoregressive moving average process (ARMA) or the autoregressive integrated moving average process (ARIMA). ARIMA models are a generalization of ARMA class models and are useful, among others, for modelling series containing a long-term trend. The ARIMA model is most often written ARIMA $(\mathrm{p}, \mathrm{d}, \mathrm{q})(\mathrm{P}, \mathrm{D}, \mathrm{Q})$, where $\mathrm{p}$ is the order of the autoregressive model, $\mathrm{d}$ - the order of differences, $\mathrm{q}$ - the order of the moving average model, $\mathrm{P}$ - is the order of the seasonal autoregressive model, $\mathrm{Q}$ - denotes the order of the seasonal moving average model, and D - the order of differences (the values of the time series with homonymous cycle phases are subtracted from each other).

The autoregressive model of AR is as follows:

$$
y_{t}=\delta_{0}+\delta_{1} y_{t-1}+\delta_{2} y_{t-2}+\ldots+\delta_{p} y_{t-p}+\varepsilon_{t}
$$

where:

$y_{t}, y_{t-1}, y_{t-2}, \ldots, y_{t-p}-$ the value of the variable in periods $t, t-1, t-2, \ldots, t-p$ respectively;

$\mathrm{d}_{0}, \mathrm{~d}_{1}, \mathrm{~d}_{2}, \ldots, \mathrm{d}_{\mathrm{p}}-$ AR model parameters;

$\varepsilon_{\mathrm{t}}$ - random component of the AR model in period $t$;

$\mathrm{p}$ - order of the AR model.

The moving average MA model has the form:

$$
y_{t}=\gamma_{0}+\varepsilon_{t}-\gamma_{1} \varepsilon_{t-1}-\gamma_{2} \varepsilon_{t-2}-\ldots-\gamma_{q} \varepsilon_{t-q}
$$

where:

$\gamma_{0}, \gamma_{1}, \ldots, \gamma_{q}-$ MA model parameters;

$\varepsilon_{\mathrm{t}}, \varepsilon_{\mathrm{t}-\mathrm{p}}, \ldots, \varepsilon_{\mathrm{t}-\mathrm{q}}-$ random components;

$\mathrm{q}$ - order of the MA model.

The ARMA model is created by combining the AR and MA models. It is defined by the formula:

$$
\begin{array}{r}
y_{t}=\delta_{0}+\delta_{1} y_{t-1}+\delta_{2} y_{t-2}+\ldots+\delta_{p} y_{t-p}-\gamma_{1} \varepsilon_{t-1}-\gamma_{2} \varepsilon_{t-2}-\ldots- \\
\gamma_{q} \varepsilon_{t-q}+\gamma_{0}+\varepsilon_{t}
\end{array}
$$

1 Stationarity means that the series is in a state of equilibrium - i.e. its most important properties, such as average level or variance, do not change over time. 
If we use formula (7) or (8) for the time series, we will obtain ARI models integrated autoregressive model and IMA - integrated moving average model, respectively. The combination of these models according to formula (9) gives the ARIMA model (i.e. the integrated ARMA model). This result may by written compactly as mentioned by Greene, 2012, pp. 983):

$$
C(L)
$$

where $C(L)$ and $D(L)$ are the polynomials in the lag operator and $(1-L)^{d} y_{t}=$ $\Delta^{d} y_{t}$ is the dth difference of $y_{t}$.

When using ARIMA models to forecast time series, problems are encountered, e.g. with determining the order of differentiation and model type. Developing models is quite labour intensive and requires specialized knowledge. The use of ARIMA models does not always guarantee better results compared to the results obtained with other, simpler methods. However, these models have the advantage that they indicate the internal structure of the series and explain the mechanism of its generation.

As a criterion for selecting the model for forecasting, the mean square error of the ex post forecast (expired forecasts) will be used:

$$
\text { RMSE }=\sqrt{\frac{1}{n} \sum_{t=1}^{n}\left(y_{t}-y_{t}\right)^{2}}
$$

This indicator measures how much the actual values of the variable deviate from the calculated forecasts. The lower the value of the indicator, the smaller the errors in forecasts.

\section{Results}

\subsection{Trend model}

In the1990-2020 period, the price of white sugar increased on average, month by month, by 0.025 cents per pound. In the same period, the price of raw sugar increased on average, month by month, by 0.024 . The estimates of the parameters of both models are statistically significant at the level of 0.01 . Adjusting the trend line to empirical data is $\mathrm{R}^{2}=0.227$ for the New York Stock Exchange (raw sugar price) and $\mathrm{R}^{2}=0.204$ for the London stock exchange (white sugar price). 
The average deviation of the empirical values from the trend line is 4.708 (NY) 5.178 (LN) cents per pound.

Table 1. Trend model for sugar prices

\begin{tabular}{|l|c|c|c|}
\cline { 2 - 4 } \multicolumn{1}{c|}{} & model & $\mathbf{R}^{2}$ & RMSE \\
\hline raw sugar $(\mathrm{NY})$ & $\begin{array}{c}\hat{y}=8.281+0.024 \mathrm{t} \\
(0.002)(0.493)\end{array}$ & 0.227 & 4.695 \\
\hline white sugar $(\mathrm{LN})$ & $\begin{array}{c}\hat{y}=11.991+0.025 \mathrm{t} \\
(0.003)(0.542)\end{array}$ & 0.204 & 5.164 \\
\hline
\end{tabular}

Source: own calculations based on sugar prices.

\subsection{Winters model}

An additive version of the Winters model was chosen. The following parameter values were obtained $\mathrm{R}^{2}$ i RMSE:

Table 2. Winter model for sugar prices

\begin{tabular}{|l|l|l|l|}
\cline { 2 - 4 } \multicolumn{1}{c|}{} & parameters & $\mathbf{R}^{2}$ & RMSE \\
\hline \multirow{3}{*}{ raw sugar (NY) } & $\alpha=1$ & & \\
& $\beta=0.001$ & 0.955 & 1.144 \\
& $\gamma=0.001$ & & \\
\hline \multirow{3}{*}{ white sugar (LN) } & $\alpha=1$ & 0.965 & 1.091 \\
& $\beta=0.001$ & & \\
\hline
\end{tabular}

Source: own calculations based on sugar prices.

This model is better suited to the time series, as evidenced by the high values of the determination coefficient and the error values of expired forecasts.

\subsection{ARIMA model}

Based on the analyses, the ARIMA model (0.1.1) (1.0.1) was selected for both time series. The estimated parameters are respectively: 
Table 3. ARIMA model for sugar prices

\begin{tabular}{|l|l|c|c|c|c|}
\cline { 2 - 5 } \multicolumn{1}{c|}{} & \multicolumn{1}{c|}{ parameters } & $\begin{array}{c}\text { Expected } \\
\text { value }\end{array}$ & $\begin{array}{c}\text { Standard } \\
\text { error }\end{array}$ & t & p \\
\hline \multirow{2}{*}{ raw sugar } & moving average (MA) & -0.238 & 0.051 & -4.654 & 0.001 \\
(NY) & seasonal autoregression (AR) & 0.890 & 0.099 & 8.973 & 0.001 \\
& seasonal moving average (MA) & 0.796 & 0.127 & 6.286 & 0.001 \\
\hline \multirow{2}{*}{ white sugar } & moving average (MA) & -0.317 & 0.050 & -6.339 & 0.001 \\
(LN) & seasonal autoregression (AR) & 0.916 & 0.063 & 14.545 & 0.001 \\
& seasonal moving average (MA) & 0.826 & 0.089 & 9.232 & 0.001 \\
\hline
\end{tabular}

Source: own calculations based on sugar prices.

The estimates of the parameters of both models are significantly different from zero. The model statistics selected were:

Table 4. Liung-Box statistics for sugar prices

\begin{tabular}{|l|c|c|c|c|c|}
\cline { 3 - 6 } \multicolumn{1}{c}{} & \multicolumn{3}{c|}{} & \multicolumn{3}{c|}{ Liung-Box } \\
\cline { 2 - 6 } \multicolumn{1}{c|}{} & $\mathbf{R}^{2}$ & RMSE & t & df & p \\
\hline raw sugar (NY) & 0.959 & 1.088 & 12.549 & 15 & 0.637 \\
\hline white sugar (LN) & 0.968 & 1.046 & 7.532 & 15 & 0.941 \\
\hline
\end{tabular}

Source: own calculations based on sugar prices.

Liung-Box statistics are used to verify the significance of deviations from zero of the autocorrelation value. The analysis shows that there are no grounds to reject the null hypothesis that the correlation coefficients are equal to zero.

In the ARIMA model, the lowest RMSE error values were obtained. For this reason, this model was used to forecast raw and white sugar prices. The sugar price forecast for the period July 2020 - June 2021 was as follows:

Table 5. Predictions for sugar prices for 2020-2021

\begin{tabular}{|l|c|c|c|c|c|c|}
\cline { 2 - 7 } \multicolumn{1}{c|}{} & \multicolumn{7}{c|}{ Year 2020 } \\
\cline { 2 - 7 } \multicolumn{1}{c|}{} & $\mathbf{7}$ & $\mathbf{8}$ & $\mathbf{9}$ & $\mathbf{1 0}$ & $\mathbf{1 1}$ & $\mathbf{1 2}$ \\
\hline raw sugar (NY) & 12.16 & 12.01 & 12.10 & 12.75 & 12.73 & 12.74 \\
\hline white sugar (LN) & 16.98 & 16.82 & 16.94 & 17.33 & 17.22 & 17.19 \\
\hline
\end{tabular}

\begin{tabular}{|l|c|c|c|c|c|c|}
\cline { 2 - 7 } \multicolumn{1}{c|}{} & \multicolumn{7}{c|}{ Year 2021 } \\
\cline { 2 - 7 } \multicolumn{1}{c|}{} & $\mathbf{1}$ & $\mathbf{2}$ & $\mathbf{3}$ & $\mathbf{4}$ & $\mathbf{5}$ & $\mathbf{6}$ \\
\hline raw sugar (NY) & 12.91 & 13.02 & 12.60 & 12.27 & 12.30 & 12.52 \\
\hline white sugar (LN) & 17.51 & 17.66 & 17.36 & 17.04 & 17.16 & 17.41 \\
\hline
\end{tabular}

Source: own calculations based on ARIMA model. 


\section{Discussion}

Fluctuations in nominal sugar prices in the analyzed period were characterized by a wide range, amounting to 27.78 cents per pound for white sugar, while for raw sugar it was slightly smaller and reached 25.74 cents per pound. On average, between 1990 and 2020, the nominal price for white sugar was 16.14 cents per pound and for raw sugar 12.70 cents per pound.

The period of the highest nominal prices on both exchanges fell in 2009-2014, during which the maximum value of nominal sugar prices was reached at 35.58 cents for the white sugar pound in January 2011 and 30.51 cents for the raw sugar pound in July 2011, respectively.

A regularity on world stock exchanges regarding sugar prices was the high amplitude of fluctuations in price dynamics over the year. The highest dynamics drops exceeding 20\% year on year were recorded in 2002 and 2018, while price reductions above $30 \%$ year on year occurred in 1999 and 2007. The highest price increases took place in 2000, 2006, 2008, 2009 and 2016 and their level even approached an increase of 50\% in 2006 and 2009. After a significant drop in prices in one year, their dynamic growth followed in the next, although there were periods when after a one-year high drop in prices, 2 years of large increases followed. However, there was no longer trend of high fluctuations in the period considered. As a result, the presented forecasting model also assumes a fairly stable level of prices in the coming months.

The above findings are consistent with the results of the research by Koo and Taylor (2012), who forecast the stability of the world sugar market in 2011-2021. Although they did not predict a high price increase in 2016, they estimated the general tendency of sugar prices around the world at the average level of 15 cents per pound well, which was confirmed in the research of the authors of this article. A similar conclusion was presented by the authors of Rumánková and Smutka (2013), who stated that the main determinants of sugar prices on world exchanges are primarily the volume of sugar production and the related surplus of inventories, as well as sugar prices in previous periods. Their research did not provide any information on the impact of government support or administrative regulations on the level and fluctuation of sugar prices in the world. 


\section{Conclusion}

The presented article describes the importance of sugar production and trade in the global economy due to its extensive links with other sectors of the economy that use it as an intermediate. That is why the level of sugar prices is so important, as they affect the profitability of related industries. Secondly, research by many authors was presented who, using various methods, attempted to predict sugar prices in different periods and in different market circumstances.

In this article, the authors have characterized sugar price trends on global stock exchanges over the period of 30 years and, based on these, using three econometric models, attempted to prepare a sugar price forecast for the next year. Their conclusions, leading to the statement that no sharp changes in sugar prices should be expected in the next year, are consistent with the results of studies based on similar statistical models. The presented research is therefore part of the discussion conducted both in the literature and among many government institutions, e.g. FAO / OECD, FAPRI or the European Commission, which prepare and publish market forecasts useful for both sugar producers and traders as well as entities using sugar as an intermediate good in its further processing.

The most important conclusion from the research is that the level of sugar prices in the world is determined primarily by market factors, rather than administrative constraints. Therefore, despite the coronavirus disease 2019 pandemic, under the influence of which the economic crisis is expected and the cessation of liberalization changes in the markets of agricultural products, including the sugar market, no significant changes in the level of prices on global stock exchanges should be expected. However, this problem will be investigated in more detail by the authors in subsequent publications.

\section{Bibliography}

Adenäuer, M. (2008). CAPRI versus AGLINK - COSIMO. Two partial equilibrium models Two baseline approaches, Poster presented on the $12^{\text {th }}$ Congress of the European Association of Agricultural Economists - EAAE 2008, 26-29 August 2008, Ghent, Belgium. Retrieved from https://ageconsearch.umn.edu/bitstream/44120/2/268. pdf (23.06.2020). doi: 10.22004/ag.econ.44120

Agrosynerie. (2011). Evaluation of CAP measures applied to the sugar sectors, Groupement Européen d'Intérêt Economique, European Commission DG Agriculture and Rural Development, Final Report.

Chow, G.C. (1995). Econometrics. Warszawa: PWN. 
Dworak, E., Grzelak, M. (2015). Conditions for The Development of Polish Agriculture in the Context of Globalization and European Integration. Comparative Economic Research, 18 (2), 6-17. doi: 10.1515/cer-2015-0009.

Gruszczyński, M., Podgórska, M. (Red.). (2004). Ekonometria. Warszawa: SGH.

Cieślak, M. (Red.). (1997). Prognozowanie gospodarcze. Metody i zastosowania. Warszawa: PWN.

Gohin, A., Bureau, J. (2006). Modelling the EU sugar supply to assess sectoral policy reforms. European Review of Agricultural Economics, 33 (2), 223-247. doi: http:// dx.doi.org/10.1093/erae/jbl006.

Greene, W. H. (2012). Econometric analysis. Pearson, International edition.

Koo, W.W., Teylor, R.D. (2012). Outlook of the U.S. and World Sugar Markets, 2011-2021. North Dakota State University, Fargo.

Kraciuk, J. (2016). Economic development of Poland against the background of other EU member states. Folia Pomeranae Universitatis Technologiae Stetinensis seria OECONOMICA, 331 (85), 69-78. doi:10.21005/oe.2016.85.4.07.

Maitah, M., Smutka, L. (2019). The Development of World Sugar Prices. Sugar Tech, 21 (1), 1-8.

Nolte, S., Buysse, J., Van Huylenbroeck, G. (2012). Modelling the effects of an abolition of the EU sugar quota on internal prices, production and imports. European Review of Agricultural Economics, 39 (1), 75-94. doi: 10.1093/erae/jbr043.

OECD. (2019). Agricultural Policy Monitoring and Evaluation.

Pörksen, N. (2012). Sustainability - an integrated part of the beet sugar industry from customer to grower. Abstract of Papers 73 ${ }^{\text {rd }}$ IIRB Congress, 14-15 February 2012, Brussels.

Prospects for EU agricultural markets and income 2015-2025. (2015). European Commission Report, Brussels. Retrieved from http://agricultura.gencat.cat/web/.content/ de_departament/de02_estadistiques_observatoris/27_butlletins/02_butlletins_nd/documents_nd/fitxers_estatics_nd/2015/0169_2015_Perspectiva_Perspectives-2015-2025-UE.pdf (14.02.2018).

Resolutions of XLIV Congress CIBE. (2015). Berlin.

Rumánková, L., Smutka, L. (2013). Global Sugar Market - the Analysis of Factors Influencing Supply and Demand. Acta Universitatis Agriculturae Et Silviculturae Mendelianae Brunensis, 61(2). doi: 10.11118/actaun201361020463.

United Nations Conference on Trade and Development. (2007). Training Module for multilateral trade negotiations of agriculture. United Nations New York and Geneva. Retrieved from https://unctad.org/en/Docs/ditctncd20067_en.pdf. (14.07.2020). 


\section{Summary}

In the article two main goals were indicated. The first is to verify the hypothesis that there is not a relevant relationship between limiting the impact of state intervention mechanisms and sugar prices on world exchanges. The second goal is to choose the best model for forecasting sugar prices after the abolition of the sugar quotas on domestic markets of sugar producers. The starting point for building the model was the time series of sugar prices on a monthly basis on world stock exchanges - London and New York in 1990-2020. One of the three models was used for forecasting. Sugar prices on world stock exchanges showed large fluctuations amounting to USD cents 28 per pound of sugar for white sugar, while for raw sugar the figure was slightly lower and reached USD cents 26 per pound. On average, in 1990-2020, the nominal price for white sugar was 16 cents per pound, and for raw sugar - 12 cents per pounds. However, the level of sugar prices in the world is determined primarily by market factors, rather than administrative constraints.

KEYWORDs: forecasting, time series, prices, sugar market.

\section{Streszczenie}

W opracowaniu wskazano dwa główne cele. Po pierwsze zweryfikowanie hipotezy o braku istotnej zależności między ograniczeniem wpływu mechanizmów interwencji państwa a cenami cukru na giełdach światowych. Natomiast drugim celem jest wybór najlepszego modelu prognozowania cen cukru po zniesieniu kwot cukrowych na rynkach krajowych producentów cukru. Punktem wyjścia budowy modelu stał się szereg czasowy cen cukru w ujęciu miesięcznym na światowych giełdach - londyńskiej i nowojorskiej z lat 1990-2020. Do prognozowania został wykorzystany jeden z trzech zbadanych modeli, za pomocą którego dokonano prognozowania cen cukru. Ceny cukru na światowych giełdach wykazywały dużą fluktuację wynoszącą dla cukru białego 497 dolarów na tonę cukru, natomiast dla cukru surowego był on niewiele mniejszy i osiągnął 456 dolarów na tonę. Średnio w latach 1990-2020 nominalna cena dla cukru białego równała się 365 dolarów za tonę, a dla cukru surowego 292 dolarów za tonę. Jednakże, to przede wszystkim warunki rynkowe miały zasadniczy wpływ na zmienność cen cukru, a nie ograniczenia administracyjne.

SŁoWA KLUCzowE: prognozowanie, szeregi czasowe, ceny, rynek cukru.

\section{Note of authors}

Anna Budzyńska - PhD in Economics, Department of Microeconomics and Applied Economics Institute of Economics and Finance, Faculty of Economics Maria Curie-Skłodowska University. Areas of specialization: macroeconomics, competitiveness, food market, agribusiness, market analysis, international trade; e-mail: anna.budzynska@umcs.pl; ORCID: 0000-0002-6959-0585.

Mirosław Piotr Urbanek - PhD in Economics, Department of Economic Policy and Banking, Institute of Economics and Finance, The John Paul II Catholic University of Lublin. The main scientific and research interests concern the issues of risk management, insurance, public procurement, management accounting and strategic management They focus on the use of multivariate statistical analysis methods and econometric models to analyze economic and financial phenomena; e-mail: miroslaw.urbanek@kul.pl; ORCID: 0000-0001-9545-6921. 